Journal of Finance and Banking Review

Journal homepage: www.gatrenterprise.com/GATRJournals/index.html

J. Fin. Bank. Review 2 (1) $32-37$ (2017)

\title{
The Influence of Global Stock Index and the Economic Indicators of Stock Investment Decision by Foreign Investors in the Indonesian Stock Exchange
}

\author{
Sulaeman Rahman Nidar ${ }^{1 *}$ and Erwin Jaya Diwangsa ${ }^{2}$ \\ ${ }^{1}$ Lecturer of Business and Management Department of Padjadjaran University, Indonesia \\ ${ }^{2}$ Alumnae of Master Management of Padjadjaran University, Indonesia
}

\begin{abstract}
Objective - The objective of this study is to determine how the movement of several indices and indicators of the global economy affect the change in investment by foreign fund flows in the Indonesia Stock Exchange (BEI).

Methodology/Technique - Some global stock indices used in this study comprise the Dow Jones index, the Nikkei 225 index, the Shanghai index (SSE) and the Singapore Index (STI). Data were taken monthly from March 2009 to June 2014. Findings - The results obtained from this study indicate that the Dow Jones index and the STI index have a significant positive effect on the movement of foreign investments in the Stock Exchange. In contrast, the movement of world oil prices and exchange rate of the IDR/USD have a significant negative effect on the movement of foreign investments in the BEI.

Novelty - The results of this study reinforces that the depreciation of the rupiah against the USD is an indication that the fundamentals of the Indonesian economy is not strong enough.
\end{abstract}

Type of Paper: Empirical

Keywords: Dow Jones, Nikkei 225 Index, Shanghai Index (SSE), STI Index, World Oil Prices, World Gold Price, Exchange Rate IDR/USD.

JEL Classification: E31, E44.

\section{Introduction}

Investment that flows into the stock market of a country is influenced by internal/domestic factors called pull factors (pull) and external/global factors called push factors. The pull factors affect the flow of investment in the form of fundamental issues surrounding the country such as inflation, national income, money supply, interest rates and exchange rates. The push factor is the driver of global influence, it acts as a form of propagation mechanism between the exchange of shares in the world (the contagion effect) and the impact of global macroeconomics (Forbes \& Rigobon, 2002; Fratzscher 2011; Rahamis, 2014). Most studies in the past examine the factors that influence the flow of investment, from both the pull factor or push factor, on the

\footnotetext{
* Paper Info: Received: January 20, 2017

Accepted: March 19, 2017

* Corresponding author:

E-mail: sulaeman.rahman@unpad.ac.id

Affiliation: Business and Management Department, Padjadjaran University, Indonesia
} 
Indonesian stock market. Abdul Karim, Majid, Shabri, Karim, and Ariffin (2009), Land and Zhang (2000), Yang et al. (2011), Kenani, Purnomo, and Maoni (2013) and Wijayanti (2013) have examined the effect of market movements on the movement of the total world stock market of Indonesia, represented by the Jakarta Composite Index (IHSG).

From their study, Abdul Karim et al. (2009) stated that the Indonesian stock market is integrated with the US stock market as well as the stock markets of Japan, Singapore and China. Darrat and Zhong (2000) observed that the US stock market and the stock market in Japan have a significant positive effect on the stock markets of the Asia Pacific region including Indonesia. It was also noted that the US stock market as well as the Singapore stock market have a significant positive effect on the stock market of Indonesia before and after the crisis of 1998 (Yang et al. 2011) whereas the stock market of Japan do not affect the Indonesian stock market before the crisis of 1998 but it has a significant positive effect on Indonesia now.

Studies looking at the effect of global macroeconomics related to commodity prices of oil and gold on investment flows into Indonesia's stock market have been conducted by Agusman and Deriantino (2008), Basher, Haug, and Sadorsky (2011), Phoong, Ismail, and Sek (2012) and Nguyen, Komornikova, Komornik, and Bhatti (2012). From their study, Agusman and Deriantino (2008) stated that the changes in world oil prices do not significantly affect the industrial sector of the Indonesian stock market. The findings contrasted the results of the study done by Basher et al. (2011) who found evidence that the world oil prices have a negative affect on emerging market countries like Indonesia. In another study, Phoong et al. (2012) showed that world oil prices can affect the stock markets of Malaysia, Singapore, Thailand and Indonesia.

Other studies carried out by Gupta, Chevalier, and Sayekt (2001) and Mukhlis (2010) examined the domestic pull factors namely the movement of the rupiah against the US dollar on the flow of foreign investments in the BEI. The researchers (Gupta et al. 2001; Mukhlis, 2010) found a negative relationship between the exchange rate of the USD against the Indonesian stock market returns. This means that if the USD strengthens against the rupiah, the Indonesian stock market index will be depressed. Vice versa, if the USD weakens against the rupiah, the Indonesian stock market index will increase.

Past studies tend to examine the factors that influence the total investment of the BEI which is represented by the stock price index (IHSG). The stock price index is the aggregate of the local and foreign investments. These investments focus on the composition of the capitalized value of foreign investments which still dominate the downward trend that is marked by strengthening local investments and by looking at the factors of global indices and global economic indicators. This is because these factors can affect the movement of foreign investments in the BEI. The focus of this study is thus to understand how these factors can impact on foreign investment flow.

\section{Methods}

This study consists of seven objectives. These objectives will be revealed through a descriptive quantitative method that is coupled with the multiple regression analysis as statistical tools.

The data used for this study comprise all the monthly data value of foreign investors (shared ownership) listed on the Stock Exchange, the world oil price (based on the standard West Texas Intermediate), the world gold price (based on the standard of the London Gold Fixing), the rupiah exchange rate against the USD (IDR/USD), the Dow Jones, the Nikkei 225 Index, the SSE Index and the STI index. The time period was taken from March 2009 to June 2014. Data were limited to the latest closure of each month during the period of observation. The data used in this research were thus, secondary data which were in the form of a readymade data publication with several obtained from the Indonesia Stock Exchange, the PT KSEI, Bank Indonesia, the Central Bureau of Statistics (BPS) and the internet.

\section{Results}

Partial testing results indicate that the movement variable of the global index of the DowJones, the STI and the movement variable of the global economy consisting of world oil prices and rupiah exchange rate against 
the USD, have a significant effect on the movement of foreign investment in the Stock Exchange. In contrast, the index movement of the Nikkei225, the SSE and gold prices do not affect the movement of foreign investment in the BEI. Special variable movement in the SSE Index has a negative correlation to movement of foreign investment in the BEI.

Based on the test results of the multiple linear estimation, the regression models can be derived as follows:

$$
\begin{array}{r}
\mathrm{CAPF}=0.015+0.42 \mathrm{DOWJ}^{*}+0.04 \mathrm{NKEI}^{\wedge}-0.07 \mathrm{SSE}^{* *}+0.55 \mathrm{STI}^{* * *}-0.14 \\
\mathrm{OIL}^{*}+0.01 \mathrm{GOLD}^{\wedge}-1.02 \mathrm{USIDR}^{* * *}
\end{array}
$$

The Regression model mentioned above concludes that the variable movement of the rupiah against the USD exchange rate is the variable that contributes most to the movement of foreign investments in the BEI.

\section{Discussion}

The period of observation in this study was noted to be from 2009 to 2014 . This is the time when the world economy was growing again after the 2008 world economic crisis. During this period, the political situation stabilized Indonesia with a relatively high economic growth as compared to other countries. Indonesia also has a huge population amounting to approximately 254 million in 2014 which is a contributor to its economic growth based on consumption (World Bank, 2015). The data export of Indonesia in total also show a rising trend which peaked in the year 2011 (BPS, 2015). In contrast, the value of the rupiah against the USD was moving on the average of between Rp 9,000 - Rp 10,000 per USD which shows a tendency to weaken since June 2011 (www.bi.go.id).

If the condition of the country's macroeconomic stock index, as examined in this study during the 20112014 period is steady, and the economic growth in the United States is also steady at an average of $3.8 \%$, then it is possible that the market in Japan would be experiencing a negative economic growth. In terms of the socio-economic condition of Japan, it is noted that other countries were also less profitable. This is because the productive age population growth was shrinking on an average of $10 \%$ since 2009 until 2014, In reverse, the increasing old age group was likely to negatively affect the economic growth expectations of Japan's future (nationalgeographic.co.id [11/07/2015]).

In the same period, while Singapore was experiencing a slightly higher economic growth than Indonesia, China was experiencing the highest economic growth in the world in the same period. This is because as the most populous country in the world with a population amounting to 1.3 billion in 2014, China serves as a huge market with a lot of potentials (World Bank, 2015). In addition, China is also a country that has the largest reserves in the world, a consequence of the implementation of a system of fixed exchange rate in the currency that is always below the USD. This system ensures that products from China can be very competitive and well supported by a stable monetary system. In trade, the trade balance between Indonesia and China (net exports) was highly skewed by the very high growth rate of $-32.57 \%$ (BPS, 2015).

If attention is given to the data export growth, it appears that companies in Indonesia, as compared to the above four countries, the trend of exports to the United States and Singapore had grown while exports to Japan and China were in the reverse (BPS, 2015) although China's export activities had decreased tremendously.

In the field of economics cooperation, Indonesia and Singapore have established cooperation in the ASEAN line up and both signed agreements of free trade area (AFTA) since 1992 and this agreement was implemented in 2002 (www.asean.org [07/11/2015]). From the period of 1989, it was observed that Indonesia had also joined the United States, China, Japan and Singapore in the APEC (Asia Pacific Economic Cooperation) cooperation where fellow members will receive special treatment in trade and investment relations starting from 2010 (www.apec .org [07/11/2015]). 
The results of this study will explain that foreign investors view Indonesia's economic growth, the economic growth of the three countries (US, Japan, Singapore) in question as well as export from Indonesia to the four countries, as factors that influenced the decision to invest in the Stock Exchange. These factors are part of the factors that affected the flow of investment into the mechanism of the BEI's theorywhich was proposed by Forbes \& Rigobon (2002).

Based on the results of this study, it can be deduced that the fact that the movement of the Dow Jones, the Nikkei 225 and the STI were positively correlated to the entry of foreign investors into the BEI, is a clear indication that foreign investors invested in the BEI so as to get a higher return. This is because the relationship of movement has characteristics similar to risks although the variable movement of the Nikkei 225 index effect was not significant (Tandelilin, 2010).

The reverse results of this study indicate that there was a negative correlation between the movement of foreign investment on the Stock Exchange on the movement of the SSE index. This implies that in relation to the SSE index movement, foreign investors made their investment in the BEI with the aim of diversifying because the SSE index variables have risk characteristics, which are opposite, although the effect is not significant (Tandelilin, 2010).

From the results noted from the descriptive analysis of the relationship between Indonesia and China and from the results of the correlation of the movement of foreign investment on the Stock Exchange on the movement of the SSE index above, it appears that foreign investors made the SSE index as a substitute for the BEI because the pull factors (pull factor) can show that the Chinese states are stronger in foreign investments than Indonesia (Fratzscher, 2011).

The results of this study also provide a further explanation, which is also noted in previous studies, that the relationship of the Dow Jones, the Nikkei 225, the SSE and the STI have is against the Jakarta Composite Index (IHSG). This suggests that a positive correlation exists between the Dow Jones, the Nikkei 225 and the STI on the IHSG, which was also revealed by Darrat and Zong (2000) and Yang et al. (2011). The results of the current study helps to explain that one of the factors that affected the IHSG's movement is the movement of foreign investments investing in the BEI.

Besides the influence of the global index, it was found that the movement of world oil price effect is statistically significant and negatively correlated to the influx of foreign investments in the BEI. From 2009 to 2014 , the average growth of the Indonesian economy had grown by 6\%. This of course requires the supply of oil to meet the industry. In that period, oil production and consumption in Indonesia were experiencing a growing inequality where the consumption showed a positive and negative growth in production such that the value of imports of petroleum continues to increase (BPS, 2015). The results of this study also explains that foreign investors still perceive that price increase and the imbalance of production and consumption of petroleum commodities, could increase cost production of companies in Indonesia. This will ultimately reduce profits.

Results of previous research suggested a negative relationship movement of world oil prices on the IHSG (Basher et al., 2011). Likewise, the results of this study also explains that foreign investors are among the factors that can affect the stock index due to the movement of world oil prices.

From this study, it can be concluded that world gold price movements do not affect the inflow of foreign investments on the BEI. In accordance with the basic assumption of the investment theory which states that basically, all investors have the properties 'risk aversion', the results of this study highlights that foreign investors make gold as a form of investment although this does not affect investments in the Indonesia stock market. This is because gold is most likely to only be used as a save-heaven as the value of gold is relatively free from the pressure of inflation, an occurrence that tends to stabilize and go up in the long term (Sunariyah, 2006).

Previous studies conducted by Phoong et al. (2012) and Nguyen et al. (2012) had also mentioned that the price of gold can affect the Indonesian stock market (IHSG) but the results of this study was slightly different. 
This outcome could be due to the behavioral factors of the foreign and local investors who each provided different responses or behavior at different observation periods.

Other foreign investment attracting factor to the BEI under study is the movement of the rupiah exchange rate against the USD. This study thus concludes that the movement of the rupiah against the US dollar has a statistically significant effect on the movement of foreign direct investment on the BEI, with an inverse correlation. These results suggest that if the USD strengthens the movement of foreign investors into the BEI moves down.

The results of this study also prove that the weakening of the domestic currency does not benefit the capital market, especially for foreign investors. The depreciating value of the rupiah can reduce the gain from their investment in the stock exchanges of Indonesia (BEI).

The results of this study reinforces what Sunariyah (2006) found, that is the depreciation of the rupiah against the USD suggests that the fundamentals of the Indonesian economy is weak. If the exchange rate is changed to represent the economic fundamentals of Indonesia, there will be a change because the exchange rate is the influence aggregate of factors of inflation, domestic interest rates, income levels, control government and market expectations (Madura, 2001). This adds to the risk for foreign investors if they want to invest in the Indonesian stock market, especially foreign investors who do not pay attention to the fundamental factor of investment activity on the Stock Exchange.

Results of previous studies (Gupta et al., 2001; Mukhlis, 2010) have explained the negative relationship between the exchange rate of the IDR/USD on the IHSG. Similarly, the results of this study further assert that the movement of foreign investment caused by the rupiah/USD exchange rate is one factor that affects the IHSG.

Based on the analysis that has been described, the following conclusions can be drawn:

a. The movement of the Dow Jones stock market index is significantly correlated $(\alpha=0.05)$ to the movement of investment by foreign investors in the BEI. In addition, the movement of the Nikkei 225 stock index is correlated with the direction of movement of investment by foreign investors in the BEI although the effect was not significant $(\alpha=0.05)$.

b. The movement of stock indices is inversely correlated to the SSE and it has no significant effect ( $\alpha$ $=0.05$ ) on the movement of investment by foreign investors in the BEI. In addition, the movement of stock indices correlated to the STI's unidirectionally with a significant effect $(\alpha=0.05)$ on the movement of investment by foreign investors in the BEI.

c. The other changes noted in world oil prices were inversely correlated and has a significant effect $(\alpha=$ 0.05 ) on the movement of investment by foreign investors in the BEI. In addition, the change in direction of gold prices correlated to the movement of investment by foreign investors in the BEI although there was no significant effect $(\alpha=0.05)$.

d. Finally changes in the rupiah against the US dollar is negatively correlated and has a significant effect $(\alpha=0.05)$ on the movement of investment by foreign investors in the BEI.

\section{References}

Agusman, A., \& Deriantino, E. (2008). Oil price and industry stock returns: Evidence from Indonesia. Social Science Research Network Working Paper Series, Aug 2008.

Basher, S. A., Haug, A. A., \& Sadorsky, P. (2012). Oil prices, exchange rates and emerging stock markets. Energy Economics, 34(1), 227-240.

Abdul Karim, B., Majid, A., Shabri, M., Karim, A., \& Ariffin, S. (2009). Financial integration between Indonesia and its major trading partners. MPRA Paper No. 17277, posted 15 September 2009

Darrat, A. F. \& Zhong, M. (2000). Permanent and Transitory Driving Forces in Asian-Pasific Stock Markets. Social Science Research Network Working Paper Series: 1-26

Forbes, K., \& Rigobon, R., (2002). No contagion, only interdependence: measuring stock market comovements. Journal of Finance, 57(5), 2223-2261. 
Fratzscher, M. (2011). Capital Flows, Push versus Pull Factors and the Global Financial Crisis, ECB Working Paper 1364.

Gupta, J., Chevalier, A. \& Sayekt, F. (2001). The Causality Between Interest Rate, Exchange Rate and Stock Price in Emerging Markets: The Case of the Jakarta Stock Exchange. SSRN Working Paper Series, Feb 2001.

Kenani, J. M., Purnomo, J., \& Maoni, F. (2013). The impact of the global financial crisis on the integration of the Chinese and Indonesian stock markets. International Journal of Economics and Finance, 5(9), 69.

Madura, J. (2001). International Financial Management, Translation: Erlangga.

Mukhlis, R. M. (2010). Analisis pengaruh harga minyak dunia, harga emas dunia dan nilai kurs dollar AS dalam rupiah terhadap IHSG di BEI (jan 2005-Mei 2010). Tesis Unpad.

Nguyen, C., Komornikova, M., Komornik, J., \& Bhatti, I. (2012). New Evidence on Asymmetric Co-movement between Gold Prices and Stock Markets with Mixed-copula Analysis. In World Finance and Banking Symposium, December (pp. 17-18).

Phoong, S. W., Ismail, M. T., \& Sek, S. K. (2013). A Markov switching vector error correction model on oil price and gold price effect on stock market returns. Information Management and Business Review, 5(7), 331-336.

Rahamis, Y. (2014). Analisis Komparasi Kinerja Pasar Modal Di Indonesia, Hongkong, China, Inggris Dan Amerika. Jurnal Riset Bisnis dan Manajemen, 2(3), 87-104

Sunariyah. (2006). Pengantar Pengetahuan Pasar Modal (Edisi ke-5). UPP STIM YKPN, Yogyakarta, Indonesia.

Tandelilin, E. (2010). Portofolio dan Investasi: Teori dan Aplikasi. Kanisius, Yogyakarta, Indonesia. 